\title{
Fighting to Leave or to Stay?
}

Migrant Workers, Redundancy and Assisted Return Programs During the Talbot Dispute, 1983-1984

Lutter pour partir ou pour rester? Licenciements et aide au retour des travailleurs immigrés dans le conflit Talbot, 1983-1984

\section{Vincent Gay}

Translator. Gabrielle Varro

\section{(2) OpenEdition}

\section{Journals}

Electronic version

URL: http://journals.openedition.org/travailemploi/6795

DOI: $10.4000 /$ travailemploi.6795

ISSN: 1775-416X

Publisher

DARES - Ministère du Travail

\section{Printed version}

Date of publication: 30 December 2015

Number of pages: 7-30

ISSN: 0224-4365

\section{Electronic reference}

Vincent Gay, «Fighting to Leave or to Stay? », Travail et Emploi [Online], Hors-série | 2015, Online since 30 December 2015, connection on 21 April 2019. URL : http://journals.openedition.org/ travailemploi/6795; DOI : 10.4000/travailemploi.6795 


\title{
Fighting to Leave or to Stay?
}

\section{Migrant Workers, Redundancy and Assisted Return Programs During the Talbot Dispute, 1983-1984*}

\author{
Vincent Gay
}

\begin{abstract}
In the late nineteen seventies and early eighties, the restructuring of the French automobile industry caused a significant reduction in the number of unskilled jobs. When the Board of directors of the Talbot factory in Poissy near Paris announced its redundancy plan in 1983, a one-month strike was launched to defend the work site and oppose the dismissals. But as the demands remained unanswered, some of the unskilled migrant workers, the first to be threatened by the redundancies, called for financial assistance to return to their home countries. Arising in the middle of the conflict, the new demand forced the strikers to reconsider their positions. Though union activists were uncomfortable with the demand, which they viewed as a renunciation to fight for employment, they ended up accepting it. As to the French government, it saw it as an opportunity, creating a new system to encourage migrant workers to go back to their countries of origin.
\end{abstract}

${ }^{66}$ Low should the Talbot events be remembered? [...] By robots trying to ship immigrants back to their villages?"1 These few words, extracted from a labour union brochure on the Talbot dispute in 1983-1984, contain in a nutshell the issues this article wishes to present.

In the 1970s, after a long period of growth that in some factories had been made possible by the massive use of migrant workers in the toughest and least well paid jobs (PITTI, 2002), the French automobile industry entered a crisis and had to be thoroughly restructured; what then was to become of the least qualified segment of the worker population confronted by the transformations of the work universe, and particularly the unskilled immigrant labourers?

\footnotetext{
* Translation: Gabrielle Varro. Article published in French in Travail et Emploi, ${ }^{\circ}$ 137, janvier-mars 2014.

** Université d'Évry-Val-d'Essonne, Institutions et dynamiques historiques de l'économie et de la société(IDHES); gayvincent@wanadoo.fr

1. «L'effet Talbot ou les raisons profondes d'un conflit », 1984, Archives interfédérales CFDT, deposit 1 B440.
} 
At the start of the 1980s, the PSA (Peugeot) group was particularly affected by the restructurings, and first of all in its Talbot plant in Poissy (Greater Paris region), where management was seeking to part with some of its unskilled labourers. Following the announcement by PSA that there would be 2,905 redundancies, between December 1983 and January 1984 a month-long strike shook the factory. It was to be an important test for all the actors involved -workers and union activists, as well as management and the French government.

In order to study the redundancies and the strike they triggered, they must first be replaced in the broader industrial, social and political environment, and in that specific factory's history and context. Without going into an exhaustive analysis of the dispute, we wish to shed some light on the stakes by taking off from one single fact: though the strike was launched to defend employment and fight redundancies, after two weeks a new demand came to the fore: financial assistance to permit immigrant workers to return to their native countries.

The demand was not voiced by the unions but by a group of striking migrant workers, which obliged the unions and the government to readjust their respective strategies. More than simply a demand, it can be considered as an event in the sense that it produced effects and displacements (BENSA, FASSIN, 2002), and must be analysed as much for what it produced as for what it said about the situation of migrant workers and how they perceived their own futures. In fact, inasmuch as it concerned a particular fraction of the worker population, the demand partly reshuffled what was at stake in the dispute, the positions of the various actors, and how to respond to the dismissals. What was at stake was as much a problem specific to the world of work -is there still space in a changing automobile industry for unskilled labourers?- as it was a problem involving the State and its policies regarding foreigners, since the lay-offs and assisted return programs challenged the very legitimacy of their presence in France.

After outlining the economic, industrial and social context of PSA and its Talbot plant, we will therefore study the impact of the demand for assisted return programs on the different actors. We will first consider the ways the strikers themselves viewed the demand: what did it communicate of their apprehension over their professional futures, their future in France, the social and economic realities confronting them? How did a demand that seemed to turn its back on the fight for jobs in fact mistreat and defy the unions? Lastly, we will see how this event represented a windfall for the French government, tempted to view voluntary return assistance as an effective way to avoid making hundreds of workers redundant.

Our study will concentrate mainly on the reactions of strikers, union members and government representatives or consultants, but an exhaustive study would also require taking other protagonists into account: non-striking employees, the embassies of immigrant workers' home countries (in particular the Moroccan Embassy), the media, migrant associations, State administrations, and of course, PSA and Talbot CEOs. 
This article has drawn on archives of different sorts: labour union sources derived from the minutes of inside meetings, sources from Company Workers' Committees, or activist material from the labour organizations, as well as documents from the cabinets of various ministries. ${ }^{2}$ Interviews carried out with participants in the dispute -former Talbot employees and union activists, as well as with a former consultant to the Prime Minister- round out our written sources.

\section{Talbot-Poissy: a Plant Characterised by Immigration and Independent Unionism}

Though marked by a long chain of emergencies like the rest of the automobile industry, given the make-up of its workforce, the crisis in the Talbot plant in Poissy unfolded in a very particular way; similarly, the forms taken by the 1983-1984 dispute can only be comprehended if replaced in the plant's social and labour-union history.

A report on the training of unskilled labourers at Talbot in 1983 contains a precise sociological description of the plant: ${ }^{3}$ of the 16,000 employees, 13,500 were workers, approximately 10,800 of them unskilled labourers (O.S.), the O.S. category representing $42.2 \%$ of French automobile wage-earners all told. At Talbot, they were mainly appointed to the assembly shop (the case of 39\% of workers overall), metal stamping and body assembly (18\%), and mechanics (8\%). Foreigners made up 52.3\% of the worker population (vs. $27.5 \%$ for the entire PSA group and $25.8 \%$ for the Renault group). The number of nationalities among foreign workers was considerable: Moroccans came first (4,402 or $58 \%$ of the foreign population), followed by Algerians (792 or $10 \%)$, Turks (5\%), Senegalese (4.5\%), Spanish (4\%), Portuguese (4\%) and Sub-Saharan Africans. Among the workers, $16.5 \%$ were under 30; $42.1 \%$ were aged 30 to $39 ; 28.8 \% 40$ to 49 and $12.6 \%$ were over 50 . In the Talbot factory, $87.6 \%$ of the foreign workers had never finished grade school, $8.7 \%$ had a grade school education (vs. 37.5\% for French workers), and 3.7\% had gone to high-school (62.4\% for the French). Job classifications reflected the same discrepancies: while the coefficient ${ }^{4}$ for $96 \%$ of the Moroccan population fell between 160 and 190, the coefficient for $86 \%$ of French workers lay between 180 and 255. The bulk of workers in Poissy were male (only $4 \%$ female) and little-skilled; as a result of the hiring policy applied since the early 1960s, the number of foreigners there was twice that of the entire French

\footnotetext{
2. Minister cabinet archives can be found at the Centre des archives contemporaines (CAC) in Pierrefitte, at the Centre des archives diplomatiques in Nantes, or in the collections assembled by Patrick Weil at "Sciences Po" (Fondation nationale de sciences politiques, FNSP/WE).

3. Travail et formation des ouvriers de fabrication de l'industrie automobile, Report of the Commission for the development of professional training for unskilled labourers, 7 January-12 October 1983, CAC, deposit 19960442, article 15 , role 3 .

4. The coefficients define the place each employee occupies in the classification grids of the companies and consequently determine their remuneration.
} 
automobile sector. Three-quarters of them (73\%) had worked at Talbot for over ten years. The assembly line or the hardest jobs were their common lot. That situation was reinforced by the fact that in-house training was aimed at skilled and highly skilled workers. As a result, most of the foreign workers, many of whom were illiterate both in French and in their mother tongue, were excluded from training. Management, the government, and even the authors of the report on the training of unskilled labourers depict migrant workers as an aging group unable to adapt to the changes at hand; yet, a very large majority of unskilled workers were under 50 . That widespread representation was to weigh on the way their future was envisioned, both inside and outside the firm. Their social relations also revealed specific features. The Poissy factory was in fact a stronghold of independent unionism since the 1950s: the French Labour Confederation (Confédération française du travail - CFT) -that changed its name to Confederation of Independent Unions (Confédération des syndicats libres - CSL) in 1977 (LOUBET, HATZFELD, 2002) - was both a tool in the struggle against the supposedly revolutionary unions - personified by the CGT and the CFDT- ${ }^{5}$ and an instrument for forcibly integrating employees, particularly migrant workers. For those who accepted, belonging to the CSL meant staying clear of problems, being well considered by their supervisors, it even meant certain benefits. Even in May 1968, the factory managed to keep clear of social conflicts. It did not, however, escape the cycle of disputes in the automobile sector that began in September 1981. All the car manufacturers and many plants, both in the Paris region and in the provinces, were impacted by strikes and walkouts of variable lengths (RICHTER, LAURET, 1983). Though in Renault and Peugeot plants workers' demands bore mainly on salaries, classifications or the organization of labour, in the Citroën factories and at Talbot, in the Spring of 1982, strikers were also demanding greater freedom and respect. A four week-long strike broke out in June 1982 against the control exercised by the CSL and the practices of management, that not only disrupted the managerial order but also ended up with unskilled migrant labourers massively joining the unions, mostly the CGT but also, though to a lesser extent, the CFDT. Assembly line delegates were chosen among them: 220 from the CGT and ca. 60 from the CFDT. For one year, the factory became the hub of a latent and quasi permanent conflict, especially against the tyranny of self-appointed, petty bosses (LOUBET, HATZFELD, 2001; GAY, 2011). ${ }^{6}$ The power struggle was transparent in the vote, since between the elections preceding the strike in May 1982 and those that followed in 1983, in the first (i.e. workers') electoral college the CSL dropped from 50.7 to $34.7 \%$ while the CGT rose from 29.3 to $42.3 \%$, and the CFDT from 5.3 to $8.2 \%$, the Confédération autonome du travail (CAT) from 6.5 to $8.1 \%$, and Force Ouvrière (FO) obtained 3.7\%. ${ }^{7}$ However, in 1983, as the threat to employment intensified, the very significance of employees' behaviour was modified.

5. CGT: Confédération générale du travail (General Confederation of Labour). CFDT: Confédération française démocratique du travail (French Democratic Confederation of Labour).

6. A similar movement for similar causes took place a few weeks earlier in the Citroën factory at Aulnay-sous-Bois.

7. Nevertheless, overall the CSL remained the majority, with $38.7 \%$, vs. $36 \%$ for the CGT and $8.9 \%$ for the CFDT. 


\section{A Sword of Damocles Over Employment and Over the Factory}

Between the two oil crises of 1973 and 1979 -the symbolic beginnings of a worldwide economic crisis- and up to the 1980s, the automobile industry underwent considerable transformations from the point of view of buy-ups and mergers as well as from the point of view of the number of factory sites and employees, or from the point of view of the organization of labour (LOUBET, 2001). Those years signaled the end of massive hiring and opened the way to large scale sub-contracting and temporary employment (Bouquin, 2006; Gorgeu, Mathieu, 2005). The PSA group was the first to be concerned by these upheavals, since in a short time, after having bought up first Citroën, then Chrysler-Europe (formerly Simca), it went from being a fairsized industrial group to being the first European corporation in the sector. But those operations did not take place at the best of times. Since the end of the 1960s, Citroën, whose sales had collapsed, faced huge difficulties, prompting the fear that it might be bought up by a foreign company or generating the specter of State intervention. Though the situation improved during the second half of the 1970s, harmonising Peugeot and Citroën was expensive and required cutting costs on both sides. As to Chrysler-Europe, its acquisition had also been prompted by the fear it might be bought up by a foreign manufacturer. But the resulting industrial group boasted more than 30 factories, 220,000 employees and produced 26 models (LOUBET, 1994): it thus became even more urgent to achieve economies of scale and coordinate the various activities. Henceforth, downsizing -the number of employees varied according to the worksitewas considered timely, and different systems implemented it: employment stopped, workers who retired were not replaced, companies lent each other employees, made considerable use of temporary unemployment and encouraged voluntary departures, pre-retirement, and the return to their native countries of migrant workers.

The early 1980s were characterised by a collapse of production and problems of productivity that made PSA less competitive. At the Talbot plant, the drop in production was more radical than in the rest of the group; it plumetted by $30 \%$ between 1979 and 1980, with 31 days not worked that year (59 in 1981). Despite a slight recovery in 1982, the beginning of 1983 again showed disturbing signs ( 25 days not worked during the first semester). In the face of these difficulties, PSA management sought to adapt to a market that had slowed down, first of all by cutting production costs, which also meant cutting salaries. Brandished by Jacques Calvet, president and general manager of PSA (LOUBET, HATZFELD, 2001), the threat that Talbot would be shut down was taken seriously by the government ${ }^{8}$ and by the CGT. On July 121983 , a massive redundancy plan was announced: Talbot was scheduled to lose 4,140 jobs. ${ }^{9}$

8. Interview with René Cessieux, technical advisor to the Prime Minister 1981-1984, in April 2013.

9. «Emploi : les grosses charrettes de Talbot-Peugeot-Citroën », Libération, 13 July 1983. 
Though several automobile factories had been or would soon be concerned by drastic cuts in personnel, the impact of the redundancy plans differed according to the social and labour union history and sociological characteristics of each firm. In the Talbot-Poissy factory, several problems came to a head at the same time: industrial reform, a commercial crisis marked by a drop in production and the beginning of automation. What is more, for various observers, the profile of the employees concerned by overstaffing confirmed the idea they were not adapted to the changes taking place in the system of production. That raised the question of how to deal with the social side of redundancies by taking the social characteristics of the targeted workers into account.

Following the decision by PSA, the analyses and orientations of the two leading labour unions that would oppose the lay-offs -the CGT and the CFDT- diverged. The CFDT wanted to raise the issue of the future of the entire automobile sector, considering it was on that level that alternatives to the destruction of jobs could be found. In particular, it endorsed the idea of reducing working time, bringing it down to the European level in conjunction with the German unions' ongoing campaign on the same theme. It also pleaded for a policy of reclassifications on the local employment markets. It expressed doubts on PSA's economic evaluations, but did not necessarily question the notion of overstaffing. ${ }^{10}$ The fight against dismissals in Poissy was thus conceived by the CFDT within the larger framework of a campaign to reduce working time. ${ }^{11}$ The CGT insisted much more on the need to save Talbot, which PSA was threatening to shut down. Though it did not discard the question of reducing working time, the CGT demanded above all that the brand be maintained, that production (of the current as well as new models) be stepped up, that the commercial networks be reorganized, new investments made and professional training developed to permit workers to adapt to the changing world of work. ${ }^{12}$ The CGT wanted to both enhance Poissy's strong points and denounce PSA's industrial strategy, which they claimed was ruining Talbot since 1978. ${ }^{13}$ Beyond its demands, CGT discourse revealed a real fear the factory might shut down, a fear shared by a part of the wage-earners and that was to weigh on the interpretation of events to come.

\section{Striking for Jobs, for the Industry, or for the Future of Migrant Workers?}

Beginning in July 1983, several sequences followed upon one another or overlapped. Between the moment the redundancies were announced in July and the month of December, the company's redeployment plan and proposals became more precise

10. « Déclaration de la CFDT au CCE du 9 septembre 1983 », Archives interfédérales CFDT, deposit 1 B440.

11. CFDT-Talbot tract, 3 January 1984, Archives interfédérales CFDT, deposit 1B440.

12. « Talbot vivra à Poissy », CGT-Talbot 4-page tract, June 1983, Archives URIF-CGT, deposit 49J568.

13. « Déclaration de la CGT au CCE du 9 septembre 1983 », Archives URIF-CGT, deposit 49J568. 
and a strike got under way during which the demand for financial assistance for migrant workers to return to their native countries surfaced.

During the Company Workers' Committee on 21 July 1983, management explained in detail how the redundancies were to take place: 1,235 people would be urged to leave on pre-retirement with the help of the National Employment Fund (Fonds national pour l'emploi - FNE) and 2,905 dismissals concerned exclusively production agents. After the rejection of the first version of its plan, PSA repeated its demand for redundancies on 21 November, accompanied by new proposals, among which the guarantee that Poissy would be spared. The idea of "making it easier for the personnel who volunteered to return to and reintegrate in their country of origin""14 figured in the plan presented by management in July and was still there in September. However, the suggestions concerning the immigrant workers were limited to the agenda of the French-Algerian agreement of $1980,{ }^{15}$ and to the possibility of taking a leave without pay, though certain schemes with the French National Immigration Office (Office national d'immigration - ONI) were not excluded. ${ }^{16}$

Between July and December, employees were in a state of wait-and-see, hanging on decisions made outside the factory which largely escaped the rank and file delegates, i.e. the backbone of a labour organization. On 24 November, there was a four-hour walk-out, and the CGT called for government intervention, stressing the fact that all the categories of personnel were concerned "from the unskilled labourer to the engineer", ${ }^{17}$ mentioning the interrogations expressed by professionals as well as technicians, and appealing to customers to come join the workers. In the face of the danger threatening the Poissy plant, the CGT sought to have all the wage-earners rally around the defense of employment, choosing to overlook the reality of the categories actually targeted by the dismissals. When the decision of 2,905 redundancies was upheld, first the CGT, then the CFDT, proposed a renewable strike until 7 December.

\section{A Strike and 1,905 Lay-offs}

Contrary to the 1982 dispute, when violent clashes marked the beginning of the strike, this time it started calmly, and in B3 -the parts assembly workshop which had already been an essential cog in 1982- production rapidly came to a halt. The lack of unity between the labour organizations was already crystal clear, and the CGT and CFDT watchwords were relatively different, but that did not dampen the enthusiasm

\footnotetext{
14. «Plan social présenté au CCE du 21 juillet 1983 », Archives interfédérales CFDT, deposit 1B440.

15. The exchange of letters between France and Algeria on 18 September 1980 concerning the return of Algerian workers and their families to Algeria, concluded an agreement that ran until 31 December 1983 and included a section on financial assistance for the return and for occupational training.

16. « Intervention de M. Collaine, président du CCE », before the Workers' Committee on 9 September 1983, Archives URIF-CGT, deposit 49J568.

17. « Pour assurer votre emploi et avec un salaire décent, débrayez massivement le jeudi 24 novembre », CGT-Talbot tract, 24 November 1983, Archives URIF-CGT, deposit 49J568.
} 
of the occupation. The ideas of the minority organization, the CFDT, ${ }^{18}$ i.e. that it was necessary to demonstrate outside the factory or to elect workshop committees to control and organize the fight, were not very popular; ${ }^{19}$ the CGT filled most of the space.

7 to 17 December was the first phase of the strike. Simultaneously, the French government, represented by Pierre Bérégovoy, Minister of Social Affairs and Jack Ralite, Minister-delegate in charge of Employment, received Jacques Calvet on 14 December, followed by the CGT. The latter expressed a certain degree of satisfaction after the meeting; the government had been reassuring on the question uppermost in CGT rhetoric: preserving Talbot. The agreement that the future vehicle $\mathrm{C} 28$ would be built at the Poissy plant seemed to herald the possibility of negotiations on "the reduction of working time, earlier retirement for workers on the assembly line, training programs, and recycling". ${ }^{20}$ The question of dismissals was not at the top of the CGT's agenda, whereas the CFDT's slogan was "zero redundancies". ${ }^{21}$ Aside from disagreeing on demands, the two unions did not see eye to eye on the form the employees' struggle should take. In fact, the CFDT did not like the way the strike had been conducted from the start because, according to them, the methods used were inherited from those applied during CFT-CSL domination, a period marked by "a strong tendency to delegate" 22 that prevents strikers from having their word to say about how a conflict should evolve.

17 December was the first turning-point. Negotiations between PSA and the government led to an agreement bringing the number of dismissals down from 2,905 to 1,905 and procuring a certain number of guarantees to those laid off: any company hiring a person dismissed by Talbot would receive 20,000 francs, each person laid off could get a F20,000 rebate on the purchase of a Peugeot vehicle in case he/she created a business; a training program would be set up for 100 employees inside and 1,300 employees outside the company, and their salary would be maintained during nine to twelve months; also, 500 reclassifications were scheduled. The CFDT Metal-Workers Federation acknowledged this as a first step (but on the worksite the union called for the strike to continue to protest the 1,905 dismissals remaining. ${ }^{23}$ The CGT's opinion was even more positive:

"solutions have been found today that will allow workers to avoid unemployment

[...]. Of the 2,905 redundancies first announced, the number has fallen by 1,000 .

\footnotetext{
18. The CFDT-Talbot section was also manned by activists who were against the Confederal guidelines led by Edmond Maire, whom they considered too conciliating vis-à-vis the Socialist government; however, the support of the Confederation to the section during the dispute created a distance between the Socialist Party and the CFDT.

19. «L'effet Talbot ou les raisons profondes d'un conflit », doc. cited.

20. «Courrier fédéral n 767, 23 Décembre 1983, spécial Talbot, Fédération de la Métallurgie CGT », Archives URIF-CGT, deposit 49J568. The CGT therefore did not rule out that Talbot employees might find work in another factory, thanks to training that Talbot could provide.

21. «Les travailleurs le crient : non aux licenciements », CFDT-Talbot tract, 21 December 1983, Archives interfédérales CFDT, deposit 1B440.

22. «Contre PSA, nous voulons peser sur les décisions gouvernementales », interview with J.-P. Noual, secretary of the CFDT section, Rouge, 16 December 1983.

23. « Nous sommes sur la bonne voie... accentuons notre pression !», CFDT-Talbot tract, 18 December 1983, Archives interfédérales CFDT, deposit 1B440.
} 
For the remaining 1,905, negotiations must get under way in the next few hours, in particular concerning long-term training periods and reclassifications with long-term contracts. What we have gained is that no Talbot worker will have to register with the ANPE [Unemployment Bureau], no Talbot worker will be out of work. It is a significant advance". ${ }^{24}$

CGT-Talbot thus called for negotiations to get under way with the factory management. When telling employees they should take into account the new situation made possible by the PSA-government agreement, the CGT did not mention any renewal of the strike. ${ }^{25}$

Though the difference between the positions of the two unions does not always seem very important, the consequences for each were considerable and the more or less latent divergencies between them sharpened. Two visions of the restructurings and the management of overstaffing at Talbot co-existed. The CGT's fear the firm would file for bankruptcy affected its evaluation of the PSA-government agreement: they especially wanted to attenuate the consequences and propose viable solutions to the employees, including outside the company. But in the factory, the potential victims of the redundancies (see Box below), had little hope for an occupational future away from Talbot. Deindustrialisation and the rise of unemployment offered slim perspectives for migrant workers with few qualifications who were sometimes illiterate and showed they were afraid of the future and attached to the firm. ${ }^{26}$ Given their impossibility to

\section{Box}

\section{Who are Those Made Redundant?}

$64 \%$ of those made redundant are production agents. The rest are warehousemen, workers in miscellaneous fields, painters, controllers, restaurant personnel, etc. $20 \%$ are French (of whom a majority comes from the overseas territories), $40 \%$ are Moroccan, $11 \%$ Senegalese, $7 \%$ Algerian. ${ }^{1}$ Besides, the criteria for dismissal seem arbitrary and do not correspond to the administration's; those concerned are workers on leave due to illness or accident, or handicapped, or over $50 .^{2}$ Also among those made redundant are 50 assembly line delegates who are members of the CGT and 15 who belong to the CFDT. ${ }^{3}$

1. « Courrier de l'adjoint au directeur de l'ANPE au président du FAS », 9 January 1984, archives FNSP/WE/32. The Fonds d'action sociale (FAS), originally intended for Muslim workers from Algeria and their families in metropolitan France, was created in 1958 during the Constantine Plan. Originally charged with doing social work with Algerian migrants during the Algerian War -it financed e.g. the first Sonacotra establishments [workers' shelters]-it then extended its prerogatives to all migrants. It was replaced by the National Agency for Social Cohesion and Equal Opportunity (Agence nationale pour la cohésion sociale et l'égalité des chances - Acsé) created in 2006.

2. «L'effet Talbot... », doc. cited

3. RichteR R. (1984), «Entre fracture et recomposition du champ social », Alternative syndicale, 2, February.

24. Press conference of the Metalworkers Federation and CGT-Talbot union, 18 December 1983, Archives URIF-CGT, deposit 49J568.

25. « Pour une juste appréciation », CGT-Talbot-Poissy tract, 19 December 1983, Archives syndicat CGT PSA Poissy. 26. That aspect had already been noted in the report Travail et formation des ouvriers de fabrication de l'industrie automobile, doc. cited 
project themselves into an occupational future, government as well as union rhetoric regarding training and professional conversion seemed totally incongruous.

\section{Return Assistance and the Shift in the Stakes of the Dispute}

A second turning-point, though relatively minor in both unions' respective chronologies of events, partly displaced the stakes of the dispute. On December 23rd, four migrant workers who were also CGT delegates organized a press conference, during which, given the deadlock, they demanded a 204,000 francs bonus to return to their native countries $;{ }^{27}$ the sum was an estimate of the cost of severance for a migrant worker, i.e. F80,000 for one year of training (salary + cost of training), F61,000 of unemployment benefits for one year at the end of the training period, F45,000 of family allowances for 30 months and F18,000 of lodging assistance. After the first rift following the 17 December agreement, and some people's incomprehension of CGT strategy, this press conference looked like a second split, and revealed the social, national or political differentiations both at the heart of the group of workers and within the labour union. Assembly line delegates on the one hand, and union activists participating in the negotiations outside the factory on the other, did not relate to the redundancies and to the conflict in the same way. Besides, CGT rhetoric sought to create a consensus and bring everyone, from the unskilled labourer to the engineer, together. In the eyes of some workers, on the contrary, that rhetoric was smothering the specific discourse they felt they alone could represent and that cannot be reduced to, nor dissolved in, a group of employees that does not care about the differences or the fracture. Their rhetoric therefore repeated that it was "up to immigrants to expose immigrants' problems in the media", ${ }^{28}$ and it was as immigrants that they wanted to be heard. They were not addressing the firms but all of France, a country that, after having become rich thanks to them owed them a "dignified reintegration" in their home countries. ${ }^{29}$ But whereas dignity, a central theme in 1982, had meant equal treatment on a par with all workers in France, the meaning shifted, dignity now being used in view of guaranteeing a future outside the factory and outside France.

It was not the first time that voluntary return assistance was mentioned since the beginning of the strike. The theme had cropped up on previous days in statements reported by journalists, ${ }^{30}$ as well as in the Employment Minister's declarations, ${ }^{31}$ or even the CGT's. ${ }^{32}$ What was unprecedented was the fact it was being expressed in public, in the thick of the battle, by an unauthorised voice, disconnected from the union system, and with return assistance as the sole demand, detached from any idea

\footnotetext{
27. See the hand-written account of the press conference on December 23, 1983, Centre des archives diplomatiques de Nantes, deposit 558PO/1/322.

28. «Talbot : "La génération usée" demande son compte », Libération, 26 December 1983.

29. Written account of the press conference, doc. cited

30. « Talbot-Poissy, la nuit la plus longue », Libération, 19 December 1983.

31. « Talbot : Ralite prêt à aider les licenciés qui souhaitent réémigrer », Libération, 22 December 1983.

32. « Talbot, discutez avec nous », L'Humanité, 20 December 1983.
} 
of training or reclassification. True, it was but a latent element, but appearing as it did during a press conference, it had considerable impact and partly reshaped the conflict. The fact that a voice the immigrants claimed represented them had found a way to make itself heard blurred the contours of the group implicated in the dispute: union activists, who speak for all workers, were no longer the only ones to speak publicly, since a part of the group, who did not define themselves exclusively by their position on the work site, was now speaking up. That profane discourse showed that different interests were at stake which, if not antagonistic, cut across the worker population and went against the mandatory class solidarity which was the union's line of attack. Such a stance therefore partly displaced what was at stake in the dispute. It forced the various protagonists to take a stand, brought actors on the scene who until then had remained exterior, and even brought in new ones. The group known as the "CGT dissidents" caught the attention of a certain number of journalists, politicians and union activists.

What claimed to represent the immigrant worker's way of thinking nevertheless contained a certain number of contradictions: for, though demanding return assistance might be interpreted as abandoning the fight for jobs -even as abandoning the fight altogether- it actually became one of the reasons to continue the fight, but in terms other than the ones propounded by the unions -preserving the firm for the CGT, zero redundancies for the CFDT. The dissidence also went further than a simple grudge against the CGT; it meant distancing themselves from union logics, apparently incapable of taking the social destiny of immigrant workers into account, contrary to what had been the case in 1982 when the interests of union activists and unskilled migrant labourers, though in some ways different, still had managed to converge.

When deciding to prolong the strike, relations with this group of migrant workers therefore became a union issue; as to the government and the firm, they looked for new interlocutors among the workers who might be able to represent those mainly concerned by the dismissals; and the issue of return assistance was potentially a way to open negotiations in view of the departure of part of the immigrant population in French industry.

\section{Fluctuating Labour Union Strategies}

The significance of immigrant workers' speaking out publicly is greater than the sole demand for return assistance. It must be considered in the more general context both of the conflict and of the Poissy plant, of the ways migrant workers became actively involved, of union practices and forms of management. What the immigrants declared at the time of the conflict and during the subsequent weeks questioned the unions' approach to the fight against redundancy as well as the way they dealt with the issue of immigration. The unauthorised immigrant voice became a matter of concern for the unions because it represented a group that each organization wanted to win over to itself. 


\section{Dissidence as a Union Issue}

After the press conference of the "CGT dissidents" the taut relations, especially between CGT and CFDT, were more and more conspicuous. Though on the work site the former still claimed to be refusing the 1,905 dismissals, its position as to continuing the strike was ambivalent, whereas, by calling for the occupation to continue, the CFDT seemed to meet the approval of a good number of unskilled labourers. Also, on several occasions the newspapers wrote that the CFDT was in the process of outdoing the $\mathrm{CGT},{ }^{33}$ which only aggravated their mutual competition and finger pointing. An attempt by plant management to have the cleaning personnel reconquer the occupied building failed, spurring bouts of violence, and followed by the workers being expelled from the factory by the CRS [storm-trooper police] on 31 December. For the government and Talbot managers, if not for certain union activists, the conflict seemed to have come to an end: as of $1^{\text {st }}$ January, the factory was cleaned and repainted. Yet on 3 January, the B3 unit was reoccupied at the behest of the CFDT, even if the number of strikers rapidly dwindled to approximately $200 .{ }^{34}$ Over the next two days, extremely violent fighting broke out in the factory: those occupying had to ward off rabid groups of employees led by the CSL, and there were many wounded. When they tried to exit, strikers were greeted by racist slogans and the Marseillaise. ${ }^{35}$ On that day, anti-strikers and the CSL were seconded by extreme right-wing activists of the Parti des forces nouvelles ${ }^{36}$ who claimed they had "come to help activists of CSL-Poissy and the whole Peugeot group from Sochaux, Aulnay, Nanterre, Rennes, Paris, etc. clean up and clean out the Poissy plant". ${ }^{37}$ There was such violence that CGT and CFDT appealed for police intervention to evacuate the strikers. The occupation and the strike thus came to an end on 5 January, while management organized the return to work under police supervision.

Despite the presence of union activists during that phase of the strike, the situation largely got out of hand and escaped union control. In that complex and confused situation, while the hostility between CGT and CFDT and mutual accusations were at their peak, the questions "who's speaking?" and "in whose name?" were all the more difficult to answer; the dissidence was denounced by the CGT as a way of inciting immigrant workers to lead their own battle, even to "organize exclusively among themselves". ${ }^{38}$ The evolutions of the dispute caused union positions -often unstable and short-lived rapprochements or distancing partly crystallised around those who spoke in the immigrants' name- to shift. After their press conference, the latter acted

\footnotetext{
33. For example, « Talbot, l'OPA de la CFDT », Le Matin, 20 December 1983.

34. «L'effet Talbot ou les raisons profondes d'un conflit», doc. cited

35. «Les douze heures de la violence », Libération, 6 January 1984.

36. Born in 1974, the PFN, while remaining in touch with the classical right wing, was for ca. ten years in competition with the National Front to occupy the extreme right-wing in French politics. After François Mitterrand was elected President, it led actions against the new government, particularly against the Communist Party, but then disappeared when the Front national began succeeding at the polls.

37. « Poursuivons le nettoyage », PFN tract distributed in Poissy on 5 January 1984, Archives interfédérales CFDT, deposit 10B34.

38. « La CGT à tous les travailleurs immigrés », CGT communique, 29 December 1983.
} 
independently from labour union structures, though the unions kept a close watch on them. By breaking away from the CGT during the last days of the strike, they seemed to be operating a rapprochement with the CFDT, who, disposing of a relatively small number of activists, hoped it had captured part of the factory's immigrant population, and toward the end of January announced that "some 35 immigrant activists, 'CGT dissidents', have at their own behest met with the CFDT section and decided to join our union. Among them are the principal immigrant leaders, particularly the Moroccans". ${ }^{39}$

Those hopes were to be thwarted in the end. After the fact, a CFDT activist felt that his union's self-confidence was not justified at the time: the dissidents, or some of them, had wanted to "play the game on their own terms, [...] they were completely lost, but they wanted to be spokesmen, they wanted to be important. But they were getting in too deep". ${ }^{40}$ At the same time, the dissidents' acts were not limited to the Poissy plant: they got in touch with other immigrant workers as well as with the young team of the "March for equality and against racism" that marched into Paris on 3 December 1983 and with whom they organized a demonstration on 14 January. ${ }^{41}$ That rapprochement concluded a seemingly contradictory alliance between immigrant workers demanding voluntary return assistance and young descendants and heirs of immigrants demanding equal rights in France. Nevertheless, it shows that a general attempt was being made to express the immigrants' point of view against the racism prevailing in France that was destroying French society, as shown, on the one hand, by the dismissal of unskilled labourers, and on the other, by racist crimes. That these workers should come forward with their own solutions, independently from labour union demands and from State injunctions, in particular by setting the amount of voluntary return assistance themselves, can be interpreted as their determination to decide their own destiny at least once in their life. But it can also pass for having internalised their inevitable exclusion from French society, signified by the radical violence of the last days of the strike.

For a few weeks, the CGT dissidents therefore found themselves in an unprecedented and uncertain militant position, acting of their own volition and at a distance from union instructions. Some were later to pursue union careers by joining Force ouvrière (FO). Though our sources do not contain actual details, a series of clues and testimonials allow imagining the various actors who made this evolution possible, among whom André Bergeron, Secretary of the FO Confederation, ${ }^{42}$ Talbot management ${ }^{43}$ or the Moroccan Embassy in France, ${ }^{44}$ which followed the conflicts in the

\footnotetext{
39. « Circulaire de la FGM aux unions Métaux », 26 January 1984, Archives interfédérales CFDT, deposit $10 B 34$.

40. Interview with Michel Beaugeois, skilled labourer and CFDT activist, March 2013.

41. « Beurs et immigrés de Talbot défilent coude à coude », Libération, 14 and 15 January 1984.

42. Interview with M'Hammed Mharam, February 2011. This former unskilled labourer and CGT delegate was one of the dissidents who later joined the FO union. Within the latter, but in a different company, he pursued a labour union career and ended up sitting on the Central European Committee of the firm that employed him.

43. Interviews with Nora Tréhel and Abdallah Fraiguy, respectively secretary and delegate of CGT-Poissy, February and May 2011.

44. « De la CGT à FO : la conversion des brebis égarées », Le Canard enchaîné, 7 March 1984.
} 
automobile industry involving Moroccan workers closely and which, since June 1982, had been putting pressure on its citizens to leave the CGT. ${ }^{45}$

That dissidence thus set off processes that escaped CGT activists when they could no longer organize the dispute. By pointing the finger at the union's divisive strategies, the dissidents were expressing a real sense of waste compared to what had begun to be built up in the labour union since the early 1980s, as well as with regard to the symbolic capital accumulated by the CGT. On 3 January, Nora Tréhel, secretary of CGT-Talbot, while claiming the right to voluntary return assistance for those who wished it, also insisted on the division that prevailed in the movement:

"But we who continue to fight are divided. We fight... but no longer for the same reasons. It's all for the highest bidder... because of the overkill. We keep piling it on. Sometimes it's no to redundancies, sometimes it's yes to redundancies in exchange for 20 million francs. What do we really want?" ${ }^{46}$

In the eyes of union activists, the "dissidents" were also showing a great lack of gratitude towards the CGT that had defended them for so many years. ${ }^{47} \mathrm{~A}$ feeling of betrayal penetrated CGT discourse in which it depicted itself as the victim of a conspiracy aiming to destabilise the only real existing opposition to the bosses and the CSL. ${ }^{48}$

The unions' attitude vis-à-vis the demand for voluntary return assistance depended on the pertinence of the demand itself as much as on the way it was transmitted and by whom. None of the unions rejected it outright, but there were subtleties in their positions; above all, whereas the CFDT hoped to capture the dissidents thanks to its commitment to the strike and by contrast with the CGT's prevarication, the latter, taken by surprise, denounced the dissidents. But in the end, the demand for return assistance was accepted, if not energetically defended, by both unions.

\footnotetext{
45. Hand-written note by the Association of Moroccan Workers in France (undated), February or March 1984, Archives du syndicat CGT PSA Poissy. Since the mid-1970s, Moroccan workers who emigrated to France and became active in the labour unions were arrested when they returned to Morocco, which was the particular case of a Talbot-Poissy worker in 1977 (interview with Driss Lafdil, October 2010). During and after the 1982 strikes, the Moroccan consulate intervened via Friends of Moroccans in France or other associations, urging Moroccan workers in the automotive industry to stay out of the unions; it also summoned union members to warn them to stay clear of politics. In the case of Citroën, see the Note by Central Intelligence (Renseignements généraux), « Des recommandations de l'ambassade du Maroc à ses ressortissants employés à l'usine de Citroën-Aulnay », 30 November 1982, Archives CAC, deposit 19960134/8. 46. « Discours de Nora Tréhel, 3 janvier 1984, dans le bâtiment B3 de Talbot-Poissy », Archives URIF-CGT, deposit 49J575.

47. See e.g. the reproach addressed to a dissident in an in-house communication: « Lettre du secrétariat du syndicat CGT-Talbot à Mohamed Chougrani », 26 January 1984, Archives du syndicat CGT PSA Poissy.

48. The CGT's account of the dispute mentions "four CGT activists [who] in collaboration with the daily Libération organized a press conference to accuse the leaders of their union. Certain media intervene directly in the conflict. A real conspiracy against the CGT is fomenting" (« Peugeot ça suffit », confederal CGT 4-page tract, January or February 1984, Archives URIF-CGT, deposit 49J568).
} 


\section{Voluntary Return Assistance: a Union Demand?}

In 1983, the principle of return assistance for immigrants was not new in France. Already in 1977, Lionel Stoléru, the minister in charge of manual and immigrant workers, had set up that sort of assistance; at the time it had been criticised and combatted by the associations supporting the immigrants, left-wing parties and the unions, the CGT calling it a "hoax". As of 1981, it had been cancelled by the new government. ${ }^{50}$ As to Talbot, it had formerly created "concerted actions of return assistance" (cancelled in 1982) that led to the departure of 629 workers. ${ }^{51}$ Nonetheless, "a certain number of (public and private) firms awarded more or less secret 'departure bonuses' that sometimes equated return assistance", ${ }^{52}$ ranging from 60,000 to 200,000 francs.

Among the unions, positions differed. As of August 1983, Force Ouvrière felt that given the tremendous difficulty for migrant employees to find lasting employment, the State must help them satisfy their wish to return to their home countries in different ways, financial assistance included. ${ }^{53}$ During its Congress in November 1983, the CSL proposed creating a "departure booklet" for "all volunteers and especially the migrant unemployed". ${ }^{54}$ For the CGT and the CFDT, the question of financial return assistance was not self-evident. The memory of the Stoléru measures was still fresh in their minds, and it was out of the question to condone a similar system. Nevertheless, little by little the demand was taken up by the unions, but in forms that revealed how uncomfortable the notion of return assistance made them feel. CGT-Talbot and the local Poissy union proposed that "if they volunteer, [workers] should say if they prefer training, a reconversion or to return to their home country with substantial indemnities". 55

Though giving lip-service to rejecting "arbitrary redundancy", ${ }^{56}$ henceforth the unions looked for individual solutions for those laid off and sought to respond to their personal aspirations, such as returning with a stipend. ${ }^{57}$ The CGT even claimed to have been the first to transmit that demand to the State authorities. ${ }^{58}$ However, the metalworkers federation and confederation were more reserved and said that for the CGT,

\footnotetext{
49. « Renvoi massif des immigrés : la CGT se dresse contre cette politique absurde, inique et dangereuse », Le Peuple, No 1018, 15-31 July 1977.

50. Decision of November 25, 1981.

51. « Note relative aux opérations concertées d'aide au retour, notamment avec l'entreprise Talbot (1980-1981)», Direction de la population et des migrations, 16 January 1984, Archives FNSP/WE/32. Aside from the redundancy bonuses that came to F10,000, immigrants who accepted to leave could choose between a bonus of F20,000 and a bonus of F16.000 with three months of training, or a nine-month training period.

52. « Note sur l'aide au retour des salariés licenciés de Talbot», Direction de la population et des migrations, 22 December 1983, Archives FNSP/WE/32.

53. «Problème Talbot : constat, réflexion et revendications du syndicat Force ouvrière des métallurgistes de Poissy, section Peugeot Talbot Poissy et de l'union départementale Force ouvrière des Yvelines », 22 August 1983, Archives interfédérales CFDT, deposit 1B440.

54. Tract. Mensuel d'information de la CSL, No 62, February 1984

55. Tract « UL CGT Poissy et syndicat CGT Talbot », 24 December 1983, Archives URIF-CGT, deposit 49 J568.

56. Ibid.

57. « Déclaration CGT Talbot », 27 December 1983, Archives URIF-CGT, deposit 49J568.

58. « Peugeot ça suffit », doc. cited.
} 
return assistance was not a national demand.$^{59}$ Though defending a different orientation in the dispute, the CFDT also felt concern over the demand for return assistance. One of its officials, active in organizing the strike, saw it as a direct result of the conflict:

"When the issue arose, it was really a reaction against the conflict itself [...]; those who were involved didn't see any way out, they saw we were going to fail and they reacted by thinking: they don't want us anymore so the only solution is to leave, but we have to get what they owe us. [...] But it was mainly anger. [...] We were impacted, we were forced to see if we were going to swallow it or not. The question was asked inside the union because there were some CFDT activists who had already begun to accept it. We tried to navigate by saying that we weren't really opposed if that was what people wanted but that the amounts demanded weren't compatible with the firms' possibilities, that it was an illusion and that in any case it wasn't a union demand., ${ }^{, 60}$

The CFDT also replaced the demand against the more general background of immigrants' apprehension linked not only to the labour cuts in industry, the rise of violence and racism, but also to

"the denunciation of Chiite fundamentalism by several government ministers when the conflicts broke out in the automobile sector in early 1983, [the] electoral victories of the extreme right on the theme of immigration, [which] reinforced the idea that cohabitation was practically impossible".

The union felt that such a demand risked isolating the workers at Talbot and compromised any likelihood of unity in the struggle to reduce working time. In this sense, return assistance was not a demand of the labour unions, but it forced itself upon them and they rallied around it, though, in the case of the CFDT, stipulating that the returns should be voluntary and not proposed only to those made redundant. Also, the union stressed another aspect of voluntary return assistance, i.e. that the workers themselves should decide how much was due them:

"the workers have said what they mean by acquired rights; they are not willing to accept 'haggling' over insufficient amounts. In that sense, the balance of power needed to obtain satisfaction in the voluntary return demand is no small thing, for without a doubt the State will hesitate to go very far so as to avoid creating precedents that any worker-French or immigrant- would then be able to demand to leave a firm in case of downsizing., ${ }^{62}$

The union was putting its finger on two important factors: who was to decide the amount letting a person leave the firm and France, and according to what criteria? If bonuses for leaving voluntarily concern all the employees in the industry, do they not represent a financial dead-end the government would prefer to avoid?

59. «Lettre d'André Sainjon à M. Mauroy », 8 January 1984, Archives URIF-CGT, deposit 49J568.

60. Interview in 2010 with Daniel Richter, engineer at Renault Flins, secretary of the CFDT Metal Workers Federation of the Seine and Oise Valley at the time of the dispute. In that capacity, he led the conflict along with CFDT activists from the Poissy plant.

61. «Les enjeux d'un conflit », CFDT-Talbot tract, 3 January 1984, Archives interfédérales CFDT, deposit 1B440.

62. Ibid. 
In both labour unions, formally refusing voluntary return assistance out of principle thus went hand in hand with accepting it, for the sake of the demand per se, because of the impasse the dispute was in and because of the socio-economic context broadly speaking. Yet, return assistance was not unanimously approved by all migrant workers, including the card-carrying ones. Some said,

“Their wishes must be taken into account. Talbot workers don't want to become 'the unemployed of 81 ' with 1,000 francs a month to survive on. If the left-wing government offers us a bonus, we'll take it; we're not going to get it later". ${ }^{63}$

But the principle of differentiation and division surrounding return assistance continued to be problematic, perhaps even more so for the Moroccan delegates. With hindsight, some of them had been wary or even rejected the measure, saying they had encouraged those who volunteered for return assistance to withdraw their application. ${ }^{64}$ One of the more senior CGT migrant delegates ${ }^{65}$ spoke up against return assistance, that he likened to haggling over his dignity. He was responding directly to the dissidents and the CFDT, questioning the meaning and the pertinence of so-called "immigrant" speech. ${ }^{66}$ Denouncing any temptation to create an immigrant union, and anything he perceived as culturalist, what he saw behind the notion of immigrant speech was the devaluation of his status as a worker:

\begin{abstract}
"When I hear some say over the CFDT microphone: 'I speak as an immigrant', it makes me jump out of my skin. What does that mean? That an immigrant doesn't possess the intellectual qualities needed to be a true labour union official? When I speak, I speak as a full union member of the CGT and as all of what I am., ${ }^{, 67}$
\end{abstract}

After seventeen years in the factory, he felt he had earned the right to speak as a worker, while the demand for return assistance cut him down to the sole status of immigrant. He opposed it with the right to occupational training that would demonstrate the capacity of immigrant workers to grow, whereas returning to their country would mark their eviction from the worker population.

Despite their different orientations in the face of the conflict and the redundancies, both unions therefore ended up by occupying relatively similar positions, consisting in accepting return assistance for those who volunteered; but volunteering in a context of crises and restructuring was ambiguous; it individualized the situations, while the fight for employment meant the response to dismissals could be collective. Volunteering and individual choice were also central in the reflexion and rhetoric of the French government.

63. «Quelques réflexions après la réunion du 7 février 1984 à la fédération CGT de la métallurgie », CGT National Secretariat for immigration, 15 February 1984, Archives Institut d'histoire sociale-CGT, deposit 105CFD32.

64. Interview in March 2013 with Yadih Baddouh, unskilled labourer and CGT delegate at the time of the dispute.

65. He joined the CGT in 1972.

66. The opposition between worker and immigrant speech during the strikes was noted as early as or even prior to the 1970s (PITTI, 2001).

67. Special tract printed by the CGT Metal Workers Federation, «Ma dignité n'est pas à vendre », interview with Abdallah Fraiguy, January 1984, Archives URIF-CGT, deposit 49J568. 


\section{Partly a Way Out for the Government}

Talbot was the first large conflict against redundancy that the government of the Union of the Left had to deal with. Taking off from the demand for voluntary return assistance, it had to respond to contradictory expectations at the same time. Creating a new system based on the Talbot case also raised new issues.

\section{Acting in the Face of the Demand for Return Assistance}

Methods to deal with mass redundancies were still rudimentary in 1983. The solution most frequently recommended was setting up a pre-retirement plan financed by the National Employment Fund (Fonds national pour l'emploi). ${ }^{68}$ Between 1974 and 1983, over two million employees, not counting steel-workers, had taken advantage of that system (CORNILLEAU et al., 1990). Return assistance, which would later be renamed "reinsertion assistance", 69 allowed firms employing large numbers of migrant workers to dispose of a full range of such methods. Therefore, when some Talbot workers applied for reinsertion assistance, the government jumped on the chance to propose new schemes. On 23 December, to get a better grasp of their grievances, the Ministry in charge of the family, population and migrant workers summoned those who had organized the press conference. The fear of being laid off in the future was topmost; it was therefore urgent to find individual solutions fast, before the situation worsened and while those workers were still of an age that a second professional career could still be imagined, for "the time that passes diminishes the chances of reintegrating in their own country". 70 The government saw this as "a new factor that it would be best to put to good use" by responding to a demand, "however short-lived", and also by showing the countries of origin that "the demand does not emanate from France alone, it also comes from their own emigrants". ${ }^{71}$ It was then necessary to "draw up concrete projects" based on hazy plans, "inciting the persons concerned to make them known, especially to their own governments", 72

Return assistance was conceived and presented as an element of the negotiation, with regard to the home countries first of all, who were not overly pleased to see their citizens return, but also with regard to the labour unions and the firm, to whom a less brutal solution than outright dismissals or hypothetical reclassifications could be proposed. The government considered setting up a new system based on the Talbot case; what the firm would offer its employees was of paramount importance, for it

\footnotetext{
68. Interview with René Cessieux.

69. Concerning the semantic and political stakes involved in the expressions "return assistance" and "reinsertion assistance" in the government's thinking, see the interview with Georgina Dufoix, Le Monde, 19 January 1984.

70. Note from Élizabeth Lion to Georgina Dufoix, Minister of Social Affairs and National Solidarity, 6 January 1984 , Centre des archives diplomatiques de Nantes, 558PO1/322.

71. Confidential communication by Alain Gillette, cabinet director at the Secretary of State in charge of the Family, the Population and Immigrant Workers, 6 January 1984, archives FNSP/WE/32.

72. Note from Élizabeth Lion to Georgina Dufoix, doc. cited.
} 
would establish the minimum that could be granted to any migrant worker being laid off in the future. ${ }^{73}$ The fate of the fired Talbot personnel was not seen as an isolated case but as a precedent on which a system permitting to imagine the departure of 20,000 immigrants from French industry could be built. Exchanges inside the government also concerned the publicity and communications that should accompany the new measures. Where should reinsertion assistance figure? Was it part of immigration policy or part of the industrial politics of employment? How should it be included in the directives concerning immigration that had been redefined in August 1983 in a more restrictive sense? How could the difference with the Stoléru return assistance system be highlighted? Also, reinsertion assistance had to satisfy contradictory expectations, those of the home countries as well as those of the "immigrant communities" who wanted a reinsertion policy but rejected any system that recalled "the "pack your bags, Mohamed!' slogan". ${ }^{74}$ And too, the expectations of French public opinion, perceived a priori as hostile to immigrants, if not xenophobic, had to be considered. The government did not intend to offer reinsertion assistance as directly in line with industrial reform; it wanted at all costs to avoid aggravating the sense of rejection and having it seen as a "good-riddance return" measure. ${ }^{75}$ On the contrary, presenting the measure at the same time as the ten-year residence permit was created pointed to a well-balanced policy capable of satisfying the "partly contradictiory" expectations of fringe sections of both French and immigrant public opinion. ${ }^{76}$

\section{The First Steps of a New System of Reinsertion Assistance}

Since the beginning of 1983, the government felt that its immigration policy was one of its least well understood policies (WEIL, 1995) and, within the framework of North-South cooperation, had implemented a new orientation that included a section on reinsertion in the native country. ${ }^{77}$ An inter-ministerial team presided by former ambassador Paul-Marc Henry, who stressed "the flexible and pioneering character of the solutions to be invented" ${ }^{78}$ while acknowledging the failure of previous procedures and the perplexity of public authorities as to what needed to be done, was set up. The objectives put forward concerning cooperation with the native countries and supposed to underscore the difference with the measures adopted by the previous government,

73. Confidential communication by Alain Gillette, doc. cited.

74. Secretary of State in charge of the Family, the Population and Immigrant Workers, 13 January 1984, Archives FNSP/WE/32. «Mohamed prends ta valise » ("pack your bags, Mohamed") refers to the return assistance system set up by Lionel Stoléru, that its critics often assimilated to a disguised expulsion.

75. Note by René Cessieux, technical consultant to the Prime Minister, and Gilles Johanet, in charge of a mission for the Prime Minister, sent to Alain Gillette, 13 February 1984, Archives FNSP/WE/32.

76. Note by Gilles Johannet, in charge of a mission for the Prime Minister, 26 March 1984, Archives FNSP/WE/32.

77. « Lutte contre l'immigration illégale et insertion des populations immigrées », communication by Madame Georgina Dufoix to the Board of Ministers, 31 August 1983, Archives FNSP/WE/17.

78. Minutes of the first meeting of the permanent inter-ministerial coordination committee for reinsertion, 10 November 1983, Archives FNSP/WE/32. 
hit up against the native countries' reticence to welcome their citizens back. ${ }^{79}$ The lay-offs at Talbot speeded up a process as yet still in its early stages and more precise propositions were exchanged during the dispute. Ministry advisors came forth with the general principles supposed to govern return assistance: it should be offered to volunteers who had been fired from their company and aim as much as possible to reinsert them professionally thanks to a cooperation that would require bilateral agreements and proscribe any unilateral, public decision. ${ }^{80}$

As the government's plans became more clear-cut, new questions arose which were just so many symptoms of the problems underlying the political conception of the new system. What would be the counterpart of the assistance granted by the State? For while acting in favor of migrant workers' reinsertion, the point was also to reduce their presence on French soil. To the French authorities, granting residence and work permits seemed the "'logical' counterpart to granting specific, financial, public assistance". 81 But it required either bilateral agreements, or a law; the former allowed enlisting the cooperation of the home countries, but eventual vetoes on their part was a liability, not to mention the fact the process would probably be very slow. A law would be faster, but it would not permit targeting specific nationalities and would spark a public debate that the government preferred to avoid. The other possibility was to create a "right to renege on the return", acknowledging the possibility that reinsertion might fail and therefore allow immigrant workers to keep their residence and work permits when leaving the firm and France. It emphasized the difference with respect to the "good-riddance return" formula of the Stoléru period and made the measure "politically acceptable in the eyes of the Left and credible in the eyes of the migrants". ${ }^{82}$ Compared to the measures decided by the previous government, this one should therefore not offend anti-racist French Left-wingers, but remain sufficiently tempting in the eyes of those primarily concerned. Who was reinsertion assistance intended for? Though the project was first and foremost a response to the fate of those laid off at Talbot, enlarging its scope was also meant to facilitate reforms in other companies where foreigners were employed. Should it then be granted exclusively to those made redundant or made available to all legal foreign workers who applied? This would reinforce the voluntary nature of assistance, keep it at arm's length from the "good-riddance return" slogan and allow keeping a cool head, contrary to the Talbot case; however, its cost as well as the reactions of French public opinion hardly encouraged the government to take that way out. What would the fate of the immigrants' beneficiaries be? The aim was to make sure that immigrants made redundant would leave and not return; yet, the fate of their spouses and children was just as important, because if they remained in France, the immigrant having taken advantage of return assistance might once again

79. Minutes of the first meeting..., doc. cited.

80. "Note confidentielle du directeur de cabinet du secrétariat d'État chargé de la Famille, de la Population et des Travailleurs immigrés", 26 December 1983, Archives FNSP/WE/32.

81. Ibid.

82. « Note sur l'aide au retour » by Gilles Johannet, in charge of a mission for the Prime Minister, 3 February 1984, Archives FNSP/WE/32. 
demand to come back pretexting family reunification. Should "constraint or simply encouragement" ${ }^{93}$ be chosen by increasing the amount of assistance? In the end, in 1983, after the first exchanges with the governments of the native countries, bilateral agreements were considered unavoidable but they turned out to be particularly prickly. Despite misgivings, the French government found itself obliged to lay down its own rules, considering that a unilateral basis could be a first step "on the way to bilateral agreements". ${ }^{84}$

Finally, a two-pronged solution was decided upon: they adopted a temporary system, exclusively aimed at Talbot's laid-off employees, which would eventually become the basis for downsizing in the case that migrant workers were involved. The "Talbot system" was built around a stipendium of 20,000 francs donated by the company, F20,000 by the Assedic [unemployment benefit fund], and, on condition they give up their residence and work permits, between F17,000 to F20,000 taken from the budget devoted to the training of Talbot laid-off personnel. ${ }^{85}$ Among the latter, during the first phase, a minority -six months after the redundancies had been announced-only 202 of those made redundant chose to apply for reinsertion assistance.$^{86}$ Later on, their number increased, much to the surprise of many employees. ${ }^{87}$ The overall system was defined as follows: ${ }^{88}$ the laid-off employee must possess residence and work permits, must have been made redundant less than six months before and employed by a firm on contract with the National Immigration Bureau (Office national d'immigration-ONI). $\mathrm{He} / \mathrm{she}$ must not be a citizen or member of the European Economic Community (EEC) or of a country in the process of becoming one, and he/she must leave France with his/ her spouse. Lastly, he/she must have a project for professional reinsertion approved by the ONI. The assistance itself consisted in a flat sum of F20,000 donated by the State, along with help for moving, a payment by the Assedic, and a stipendium from the firm at least equal to that of the State. On the average, a beneficiary received approximately F90,000 ${ }^{89}$ Over the 1980s, the system evolved, especially so as to include long-term unemployed, 1985 being the peak for returns, with the departure of 32,898 persons.

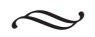

The 1983-1984 strike must be seen as part of the cycle of crisis that hit the automobile industry in 1981 and ended mid-1984 with the redundancies announced by

83. « Note sur l'aide au retour », doc. cited.

84. Note by Élizabeth Lion à Georgina Dufoix, 29 février 1984, Archives FNSP/WE/32.

85. «Relevé de décisions de la réunion interministérielle du 2 janvier 1984 », Archives FNSP/WE/32.

86. «Liste des personnels licenciés par Talbot début 1984 ayant déposé un prédossier de réinsertion », 19 June 1984, CAC, deposit 19940732/2.

87. Jean-Pierre Noual, secretary of CFDT-Talbot, admitted having been wrong about return assistance, observing that "it worked". $C f$. « Le vertigineux succès de l'aide au retour », Le Matin, 25 June 1985.

88. Decree of 27 April 1984 and Law of 17 July 1984.

89. Note from Christian Nguyen, Technical advisor at the Ministry of Social Affairs and National Solidarity, to Charles-Henri Filippi, Director of the Georgina Dufoix cabinet, 20 August 1984, Archives FNSP/WE/32. 
Citroën. There were distinct phases. Until the beginning of 1983, the conflict was aggressive, workers demanded rises in salary, better working conditions, the freedom to organize and the respect of their dignity. In the Citroën and Talbot plants, the 1982 strikes thus seemed to be making an inroad into French social life and union participation. Yet, a year and a half later, part of the strikers, of immigrant origin, applied for assistance to leave their firm and France. Such a reversal interrogates the conditions prevailing during the previous conflict at Talbot, where particular circumstances had made a victorious strike possible. However, as soon as maintaining the jobs looked hopeless, workers turned to return assistance. The demand for maintaining jobs alternated, collided, even competed with demands for return assistance, but it was only when the fight for employment petered out that the demand for return assistance gained momentum and led to all the actors - union activists, unskilled migrant labourers, management, and the French government- having to redefine where they stood. Representing a stake in the battle or a divisive element for some union activists, the demand for return assistance nevertheless ended up creating a form of consensus backed by the notions of individual choice and volunteering. Nevertheless, it was an ambiguous sort of consensus, because it raised the question whether it was legitimate for migrant workers to be in France, while simultaneously those for whom immigration represented a problem wanted to send them back to their home countries. ${ }^{90}$ In the context of the early 1980s, the notion of choice imperfectly covered up the fact that the return was part of the State's conception, for whom the legitimacy of immigrants' presence in France depended on their status as workers (SAYAD, 2006). The immigrants themselves, or at least some of them -and the labour unions, when they were no longer able to defend employment- shared that point of view, of which the return to the home country was a basic component.

Besides, while reinsertion assistance was aimed at a particular segment of the employee population, it was also one of the many measures by which the State could socialise the cost of industrial reform. Since the mid-1970s, and progressively more as the crisis deepened, the successive governments had chosen to follow the same route, inciting firms to undertake economic redundancies, especially as withdrawing certain categories of workers from activity had been facilitated (Colin et al., 1981). Between 1973 and 1988, the costs of the employment policy increased proportionally, from $0.9 \%$ to $3.5 \%$ of the gross domestic product (GDP) ${ }^{91}$ (CoRnILlEaU et al., 1990). Throughout the 1980s and 90s, age considerations were applied particularly in the automobile sector to whittle down the permanent workforce; measures regarding migrant workers obeyed the same logics, because they permitted avoiding some outright dismissals while at the same time reducing the number of stable jobs.

Other aspects that impacted every echelon from the workshops to the highest spheres of the State would require further study in order to come to terms with all the dimensions of the conflict. Each domain -the politics, the labour unions, the industry,

90. « Le retour, une arme à double tranchant », interview with Ahsene Zehraoui, Libération, 14 and 15 January 1984. 91. Employment costs here cover unemployment benefits, pre-retirement and occupational training for working adults. 
etc.- would deserve scrutiny on different levels. For instance, the way immigrant union delegates operated in the workshops was clearly at odds with the practices of their union leaders; but given their respective social positions, what sort of coherence can exist between a striker and a negotiator? The same question goes for company executives, torn between the directors of the group on one side and the plant managers facing the dispute in the field on the other. During the tense period when labour disputes challenged ongoing political changes and the balance of power, local politics might also be analysed, particularly in Poissy where, in 1983, the Communist mayor, formerly a CGT secretary at the automobile factory, and husband of the acting secretary, was beaten by a representative of the Rassemblement pour la République (RPR), formerly a member of the CSL. Without going into the strict causality of the factors at play in the various domains, one may wonder about their permeable nature and how the actors were affected by it.

Finally, the conflict cannot be correctly understood if one does not take the political context into account. The first electoral victories of the French National Front and the 1983 campaign for the Municipal elections testified to the powerful rise of xenophobia among voters; that factor contributed to the government's new policies on immigration, but it also modified unskilled migrant labourers' perception of the future. It is therefore indispensable to consider employees' situations in a broader context than the economic reality of the firms, in order to appreciate the extent to which that context moulded their perception of the stakes and the opportunities.

\section{REFERENCES:}

Bensa, A., and Fassin, E. (2002). « Les sciences sociales face à l'événement. » Terrain, 38, 5-20.

Bouquin, S. (2006). La valse des écrous : travail, capital et action collective dans l'industrie automobile. Paris: Syllepse.

Colin, J.-F., Gros, J.-C., Verdier, E., and Welcomme, D. (1981). « Politiques d'emploi : la rupture de 1977, éléments pour une analyse critique des politiques spécifiques d'emploi (1974-1980). » Travail et Emploi, 10, 9-22.

Cornilleau, G., Marioni, P., and Roguet, B. (1990). « Quinze ans de politique de l'emploi. » Revue de l'OFCE, 31, 91-120.

GAY, V. (2011). De la dignité à l'invisibilité : les OS immigrés dans les grèves de Citroën et Talbot, 1982-1984. (Mémoire de master 2, Paris, EHESS).

Gorgeu, A., and Mathieu, R. (2005). «Les restructurations industrielles : une fatalité du marché ? Le cas de la filière automobile en France. » Revue de l'Ires, 47, $37-58$.

LOuBET, J.-L. (1994). «PSA Peugeot-Citroën, 1973-1992. Histoire d'un groupe automobile dans les années de crise. » Actes du Gerpisa, 10.

Loubet, J.-L. (2001). Histoire de l'automobile française. Paris: Seuil. 
Loubet, J.-L., and HatzFeld, N. (2001). Les sept vies de Poissy : une aventure industrielle. Paris: ETAI.

Loubet, J.-L., and HATzFeld, N. (2002). « Poissy : de la CGT à la CFT, histoire d'une usine atypique. »Vingtième Siècle. Revue d'histoire, 73, 67-81.

PiTTI, L. (2001). « Grèves ouvrières versus luttes de l'immigration : une controverse entre historiens. » Ethnologie française, XXXVII(2), 465-476.

PITTI, L. (2002). Ouvriers algériens à Renault-Billancourt de la guerre d'Algérie aux grèves d'OS des années 1970. Contribution à l'histoire sociale et politique des ouvriers étrangers en France. (Thèse de doctorat d'histoire, Université Paris-8).

Richter, D., and LAURET, F. (1983). « Dix-huit mois de conflits à la chaîne. » Travail, spécial issue, 8-34.

SAYAD, A. (2006). L'immigration ou les paradoxes de l'altérité, tome 1 : L'illusion du provisoire. Paris: Raisons d'agir.

WEIL, P. (1995). La France et ses étrangers : l'aventure d'une politique de l'immigration de 1938 à nos jours. Paris: Gallimard. 